\title{
Socio-Economic Factors Influencing Adoption of Sweet Potato Production Technologies among Farmers in South East, Nigeria
}

\author{
Okeke, M.N. ${ }^{1}$ and Mbah, E.N. ${ }^{2}$ \\ ${ }^{1}$ Department of Agricultural Economics and Extension, Chukwuemeka Odumegwu Ojukwu University Anambra \\ State, Nigeria \\ ${ }^{2}$ Department of Agricultural Extension and Communication, Federal University of Agriculture Makurdi, Nigeria \\ *Corresponding Authors: Mbah, E.N, Department of Agricultural Extension and Communication, \\ Federal University of Agriculture Makurdi, Nigeria
}

\begin{abstract}
The survey was carried out to identify socio-economic factors influencing adoption of sweet potato production technologies among farmers in South East, Nigeria. Data were collected from a sample of one hundred respondents (100) using questionnaire. Mean score, standard deviation, factor analysis and multiple regression analysis were used for analyzing data collected for the study. Findings revealed that socioeconomic factors such as age, educational level, farming experience, membership of organization, access to extension services and annual income had significant relationship on adoption of sweet potato production technologies in the study area. Results also showed major constraints to adoption of sweet potato production technologies which were inadequate capital for start- off $(\bar{x}=3.00)$, limited access to credit facilities $(\bar{x}=$ 2.94), high incidence of pests and diseases infestation $(\bar{x}=2.94)$, high cost of inorganic fertilizer $(\bar{x}=2.93)$, inadequate agro-input incentives like herbicides, $(\bar{x}=2.86)$, high cost of labour $(\bar{x}=2.84)$, unavailability of improved planting material (vine) $(\bar{x}=2.82)$, high cost of improved varieties $(\bar{x}=2.75)$, poor road network for produce transportation $(\bar{x}=2.73)$, herdsmen attack/ cattle menace $(\bar{x}=2.65)$, poor soil fertility $(\bar{x}=$ 2.59), lack of technical knowledge of improved agronomic practices $(\bar{x}=2.58)$, among others. The constraint variables were also subjected to factor analysis which were named input, climate and poor management factors. The study recommended that there is need to improve the productivity of farmers by encouraging increased use of improved production technologies through practical oriented short training program designed to build the capacity of the producers and adequate provision of facilities that will be appropriate for its usage in order to maximize profit.
\end{abstract}

Keywords: Socio-economic factors, adoption, sweet potato, production, technologies, Nigeria

\section{INTRODUCTION}

Sweet potato (Ipomoea batatas) is a short duration crop with high yield and economic returns (International Potato Center (CIP), 2010). It is the only root and tuber crops that can be grown and harvested within four months in Nigeria. Specifically, sweet potato can be grown two to three times in a year with supplementary irrigation (National Root Crops Research Institute (NRCRI), 1996). It has low soil fertility requirement and better opportunity cost relative to the other root and tuber crops such as cassava, yam and cocoyam (Food and Agriculture Organization (FAO), 2012).

Sweet potato is highly adaptable to relatively marginal soils and erratic rainfall, has high productivity per unit of land and labour and guarantees some yield even under the most adverse conditions (Ogbonna, Nwauzor, Asumugha and Emehute, 2005). Sweet potato is a low input crop. It is a good source of vitamin $\mathrm{C}$ and pro-vitamin $\mathrm{A}$, and can be substituted for maize in livestock production (NRCRI, 1990). Ipomoea batatas does not have the problem of anti-nutritional factors such as cyanides and oxalates that exist in cassava and cocoyam respectively (Abubakar, Olayiwola, Sani and Idowu, 2010). Furthermore, its high yield potentials and short life cycle of less than 20 weeks make crops like yam (Dioscorea spp) relatively poor competitors for general industrial starch (NRCRI, 1990).

Sweet potato can be regarded as poverty alleviation crop. According to Nigerian Demographic and Health Survey (NDHS) (2008), investing in orange- fleshed sweet potato improves food security in 
Nigeria in terms of food access, it has relatively low labour requirements compared to yam, cassava and maize and post- harvest techniques can improve storage life and access to fresh roots among rural and urban consumers. In addition, the fortification of sweet potato bakery products by replacing 20$40 \%$ of wheat flour with sweet potato flour and other products improves the accessibility and shelf life of sweet potato.

Different varieties have been developed and selected for different agro-economic conditions and uses. Sweet potato varieties differ from each other in many ways, including leaf shape and colour, vine structure, root shapes, root skin colour, flesh colour, taste, texture, dry matter content yield, resistance to pests and diseases (Reaching Agents of Change (RAC), 2012). According to Woolfe (1992), sweet potato has broad categories: the staple type with white fresh and white or purple skin with high starch and dry matter content and the dessert type with orange flesh and orange skin with a high sugar and beta- carotene content, among others.

According to NDHS (2008), a wide range of sweet potato based processed products such as bakery products, juice, chips, crisps, flour, cereal and noodles can open up new markets for food industry. Sweet potato contributes extensively to world food production, food and nutrition security and income generation. Sweet potato helps in building up a viable and competitive root and tuber crop industry which provides consumers with high quality fresh and value added products.

The Federal Ministry of Agriculture, United Nations, government institutions and universities are involved in research on sweet potato (United Nations Administrative Committee on Coordination, 1994). Among these institutions, the National Root Crops Research Institute (NRCRI) Umudike, and the International Institute of Tropical Agriculture (IITA), Ibadan have the national mandate to conduct research on the genetic improvement, production, processing, storage, utilization and marketing of root and tuber crops of economic importance, including sweet potato (Federal Government of Nigeria (FGN), 2011). Extensive research work on sweet potato has been going on at the NRCRI since 1976 when NRCRI took leadership in the research on root and tuber crops in Nigeria. Research activities carried out include germplasm collection; breeding; conservation and evaluation; agronomic research; pests and diseases management; post-harvest handling (processing), distribution and socio-economics of sweet potato production (Olufloaji, 2012).

Sweet potato roots are used for human consumption, the criteria used for breeding and selections have been based on parameters related to food preferences such as taste, texture, water and fibre content. Selections for industrial uses emphasize canopy structure, root size and dry matter content. These research efforts have led to the introduction of improved varieties such as TIS 87/0087, TIS 2532.OP.1.13, TIS 8441 and TIS 8164 which are high yielding and tolerant to prevalent pests, notably sweet potato weevil (Cylas spp.). The varieties TIS 8164, TIS 87/0087 and TIS 2525.OP.1.13 have wide adaptation across Nigeria which resulted in the increase in yields of sweet potato (NRCRI, 2009).

Improved sweet potato varieties which are projected to offer yield gains of $20 \%$ compared to healthy local landraces, higher micronutrient content, dry matter content, sugar content and taste which can improve the market demand and nutritional value of individuals are not easily adaptable to local environments of rural communities. Ochuba, Okonkor, Omenukor and Akuma (1983) carried out an adaptation study on nine improved sweet potato varieties showing that six of the improved varieties gave significantly higher yields than the local varieties at Ubiaja and Umudike and four of the improved varieties out-yielded the local variety (control) at Igbariam station. The result showed that the local varieties at Lafia gave significantly higher yields than the improved varieties.

There is need to determine how planting materials of different varieties can be made available in the market or elsewhere. Maintenance of planting materials during the prolonged dry season is a challenge and results in delayed plant multiplication. Sites must be established and awareness created to entrepreneurs who will be ready to buy. A sustainable farmer- based and managed seed multiplication must be established. Therefore, in order to have access to good planting materials/vine cuttings, Nwinyi and Onyenobi (1987) findings indicated that the recommended method of preserving vine cuttings of sweet potato is by storing them in open baskets. Their findings showed that a preservation method such as covering the vines with dry matter reduces the fresh tuber and saleable tuber yields by $20.2 \%$ and $18.2 \%$ respectively. 
The potentials of adoption of sweet potato production technologies cannot over estimated and this gave rise to these research questions that are pertinent to this study. What is relationship between farmers' socio- economic characteristics and adoption of sweet potato production technologies? What are the constraints to adoption of recommended sweet potato production technologies?

Specifically, the study sought to:

- determine the relationship between socio-economic characteristics of farmers and adoption of sweet potato production technologies; and

- identify constraints to adoption of sweet potato production technologies.

\section{MeTHOdOLOGY}

The study was carried out in South-East, Nigeria. Abia and Anambra States were selected out of the five states in South-East, Nigeria because of existence of National Root Crops Research Institute, Umudike and Federal Research Institute, Igbariam. Also, sweet potato is mainly produced in these States.

Abia State is one of the five states in the South-East geo-political zone of Nigeria with Umuahia as its capital. Abia State is made up of seventeen (17) Local Government Areas which are grouped into three agricultural zones namely; Aba, Ohafia and Umuahia. It is located between latitudes $04^{\circ} 45$ and $06^{0} 07 \mathrm{~N}$ and longitudes $07^{\circ} 10$ and $08^{\circ} 10 \mathrm{E}$. The state is bordered by Imo, Anambra and Rivers State in the West, North West and South West respectively. To the North, North East, East and South East, it is bordered by Enugu, Ebonyi, Cross Rivers and Akwa Ibom States respectively. It has a population of 2,833,999 people with 70\% living in the rural areas (National Population Commission (NPC), 2006). It covers a land area of 776,720 square kilometres. The climate is tropical with dry and rainy season which starts in March and lasts to the end of November, with a peak period in June while dry season starts from December to February. Abia State has an annual rainfall of about $668 \mathrm{~mm}$. A large proportion of the people are engaged in farming and they produce mostly yam, cassava, cocoyam, banana, maize, sweet potato, rice, plantain, oil palm, cocoa, rubber, cashew, garden egg, among others. They also engage in the rearing of livestock such as poultry, goats, sheep and rabbits. Umudike is in Abia State which is the seat of the National Root Crops Research Institute that began as a provincial farm in 1923, up-graded to Commodity Research institute in 1975 and renamed as National Root Crops Research Institute in 1976. The institute is mandated to research into the genetic improvement, production, processing, utilization, storage and marketing of root and tuber crops in Nigeria which include yam, cassava, sweet potato, Irish potato, ginger and minor root crops as well as research into the total farming systems of South- East agro-ecological zone comprising Abia, Anambra, Ebonyi, Enugu and Imo State.

The activities of sweet potato production and processing in the states particularly at NRCRI include careful development of new populations with higher probability of combining traits in a genotype through hybridization and this has been adopted for the sweet potato value chain programme of the Federal Ministry of Agriculture and Rural Development, selection of varieties with high root yield, identifying and duplicating parents that flowers for inclusion in the germplasm for crop improvement, soil management and agronomic technologies that are necessary for the improved varieties of sweet potato and farming systems.

Anambra State is one of the 36 States of Nigeria situated in the South- Eastern part of Nigeria. The State is made up of twenty one (21) Local Government Areas (LGAs). The State is divided into four agricultural zones namely; Aguata, Anambra, Awka and Onitsha with five, four, five and seven extension blocks, respectively. The state is located between latitude $5^{0} 38 \mathrm{~N}$ and $6^{0} 47 \mathrm{~N}$ and longitude $6^{0} 36 \mathrm{E}$ and $7^{0} 21 \mathrm{E}$. It has Abia, Delta, Enugu, Imo and Kogi State as its neighbouring states. Anambra State occupies an area of $4,416 \mathrm{~km}^{2}$ and has a population of 4,177,828 out of which 2,117,984 are male and 2,059,844 are female (NPC, 2006). It has $70 \%$ available land and less than $55 \%$ of the available land is under cultivation. The number of farm families was reported by (Anambra State Agricultural Development Programme (ASADEP), 2013) as 338,721 with an average size of 8 persons per household. It has two main seasons, the dry and the rainy seasons with annual rainfall between 2000 and $2300 \mathrm{~mm}$. The soil type and climate of the area are suitable for sweet potato 
production in many parts of the State making it to stand out as one of the largest producers of sweet potato in Nigeria with production figure of 159mt (Ministry of Agriculture Awka, 2015).

The population of the study comprised all sweet potato processors in Abia and Anambra States, South-Eastern Nigeria. A total of 100 respondents were selected using a multi-stage sampling procedure. Stage 1 involved random selection of five local government areas each from Abia and Anambra States. The LGAs selected were Ikwuano, Bende, Aba North, Aba South and Ohafia in Abia State; Anambra West, Ogbaru, Awka North, Anambra East and Ayamelum in Anambra State. Stage 2 involved a random selection of two communities from each LGA to give a total of 20 communities. Stage 3 involved random selection of 5 farmers from each selected communities using simple random sampling techniques, giving a total sample size of 100 respondents used for the study.

Data were collected using questionnaire. Mean score, standard deviation, factor analysis and multiple linear regression analysis were the statistical tools used for analyzing data for the study.

\section{RESULTS AND DISCUSSION}

\section{Relationship between Farmers' Socio- Economic Characteristics and Adoption of Sweet Potato Production Technologies}

Results of regression analysis of the relationship between the independent variables (age, educational level, farming experience, social organization belonged, access to extension services and annual income) and adoption of sweet potato production technologies in Abia and Anambra States show that a strong correlation $(\mathrm{R}=0.857)$ exists between dependent variables and independent variables (Table 1). These variables were able to explain $77 \%$ of the variation in adoption of sweet potato production technologies among producers $\left(\mathrm{R}^{2}=0.769\right)$. Adjusted $\mathrm{R}^{2}$ also supported the claim with a value of 0.676 or $67.6 \%$. This shows that the independent variables explain the behaviour of the dependent variable at $67.0 \%$ level of confidence. Out of the twelve variables investigated, six variables were found to be statistically significant for adoption of sweet potato production technologies. They included were age, educational level, farming experience, membership of social organization, access to extension service and annual income.

Age is one of the socio-economic determinants of adoption of sweet potato production technologies in the study area. Age of the producers was positive and significantly influenced the adoption of sweet potato production technologies. This implies that any increase in age will lead to a corresponding increase in the adoption of the improved sweet potato production technologies.

Education level showed a positive relationship with adoption of sweet potato production technology. A unit increase in the level of education increased the probability of the adoption of sweet potato production technologies. Producers are more disposed to understand new ideas and concepts provided by extension workers and other informants. This underlines the importance of human capital development in increasing the level of the improved sweet potato production technologies. This agreed with Aniedu and Aniedu (2013) who pointed that education is very essential in the development process.

Years of farming experience was positive and significantly influenced adoption of sweet potato production technologies in the study area. This shows that the contribution of explanatory variables is proportional to dependent variables. This implies that the more farming experience producers had, the higher the productivity of sweet potato in the area. Years of experience could mean practical knowledge acquired especially through trial and error and having established the best method. This is in line with the findings of Okoye, Dimelu, Okoye and Agwu (2009) which stated that the more experienced a farmer is, the more efficient he/she will be in decision- making processes and he/she would be willing to take risks associated with the adoption of innovations.

Membership of social organization was the fourth variable perceived by the producers that influenced the adoption of sweet potato production technologies. It had a positive influence which implies that it is directly related to the dependent variable. Therefore, the higher the number of those that did not belong to a social organization, the lower the rate of adoption of improved sweet potato production technologies. Thus, for adoption rate to be maintained as regards to sweet potato production, membership of social organization has to be effective. Extension contact had a positive influence on 
the adoption of sweet potato production technologies in the study area. This implies that frequent contact with extension agents by the producers gives them opportunity to know about the use of improved sweet potato production technologies that will increase their production while no contact with extension agents will affect their production due to the fact that they have missed information on the basic inputs needed for production. Therefore, regular contact with extension agents makes producers aware of improved innovations and how they can apply them to improve their livelihood. This is in line with Nwachukwu (2014) who noted that it is only through an effective communication pattern that the behaviour of the receiver will change to the desire of the source.

Annual income had a positive influence on the adoption of sweet potato production technologies in the area. This implies that the more income realized by the producer, the higher the productivity leading to high adoption rate of sweet potato production innovations provided that all things being equal. On the other hand, it also shows that the lesser the annual income, the lower the productivity of the crop, thus low adoption of the technologies. Similarly, the positive relationship was in agreement with Alinor (2002) because as capital increases, the scales of production are also being enlarged and this translates to more increase in output.

Table1. Regression model for the relationship between farmers' socio-economic characteristics and adoption of sweet potato production technologies

\begin{tabular}{|c|c|c|c|c|}
\hline \multicolumn{5}{|c|}{ Standardized Coefficient } \\
\hline Variables & $\mathbf{B}$ & SD Error & Beta & $\mathbf{T}$ \\
\hline Constant & 1.976 & 0.881 & - & 2.654 \\
\hline Age & 1.343 & 0.246 & 0.824 & $8.911 *$ \\
\hline Sex & -0.700 & 3.630 & -0.020 & -0.193 \\
\hline Educational level & 1.578 & 0.517 & 0.529 & $4.023 *$ \\
\hline Household size & 0.170 & 1.661 & 0.017 & 0.102 \\
\hline Marital status & -2.284 & 1.735 & -0.141 & -1.316 \\
\hline Farm size & 0.045 & 0.029 & 0.238 & 1.731 \\
\hline Farming experience & 1.627 & 0.337 & 0.294 & $3.941 *$ \\
\hline Source of fund for take-off & 0.053 & 0.346 & 0.023 & 0.245 \\
\hline Source of farm labour & 0.047 & 0.276 & 0.015 & 0.175 \\
\hline Membership of organization & 0.955 & 0.341 & 0.307 & $3.066 *$ \\
\hline Access to extension service & 1.732 & 0.533 & 0.518 & $4.035 *$ \\
\hline Annual income & 1.512 & 0.305 & 0.372 & $2.791 *$ \\
\hline
\end{tabular}

$* \mathrm{P} \leq 0.05, \mathrm{R}=0.857, \mathrm{R}^{2}=0.769$, Adjusted $\mathrm{R}^{2}=0.676$

\section{Constraints to Adoption of Sweet Potato Production Technologies}

Table 2 shows major constraints to adoption of sweet potato production technologies which include inadequate capital for start- off ( $\bar{x}=3.00)$, limited access to credit facilities $(\bar{x}=2.94)$, high incidence of pests and diseases infestation $(\bar{x}=2.94)$, high cost of inorganic fertilizer $(\bar{x}=2.93)$, inadequate agro-input incentives like herbicides, $(\bar{x}=2.86)$, high cost of labour $(\bar{x}=2.84)$, unavailability of improved planting material (vine) $(\bar{x}=2.82)$, high cost of improved varieties $(\bar{x}=2.75)$, poor road network for produce transportation $(\bar{x}=2.73)$, herdsmen attack/ cattle menace $(\bar{x}=2.65)$, poor soil fertility $(\bar{x}=2.59)$, lack of technical knowledge of improved agronomic practices $(\bar{x}=2.58)$, poor yield $(\bar{x}=2.29)$, rodent attacks $(\bar{x}=2.07)$, poor storage facilities $(\bar{x}=1.95)$, inadequate cultivable land $(\bar{x}=1.90)$, lack of market ( $\bar{x}=1.81)$, use of local varieties $(\bar{x}=1.79)$ and poor extension contact ( $\bar{x}=1.66)$. The minor constraints were bush burning/fire outbreak $(\bar{x}=1.47)$, excessive rainfall $(\bar{x}$ $=0.99)$ and difficulty in integrating sweet potato production technologies into existing production system $(\bar{x}=0.91)$. This is an indication that inadequacy of fund constrained producers from adopting improved technologies. Major constraints to sweet potato production technologies limit the producers from adopting sweet potato production technologies. This is attested by some scholars (Ugwumba and Omojola, 2012; Ajah, 2015). These major constraints have impacted negatively on the overall agricultural production in Nigeria. Nwaigwe, Echendu, Nwachukwu, Ewuziem and Nwako (2011) reported that $90.8 \%$ of sweet potato farmers in Abia State lacked sweet potato planting materials as a result of poor storage system for maintenance of planting materials for the next planting season. This is confirmed by Ejechi, Aboaja, Anyaegbunam, Asumugha, Njoku and Okoye (2010) that 
unavailability of planting materials contributed to constraints to sweet potato production in the Federal Capital Territory. The findings are in line with Obike, Emerole and Eze (2014); Okoro and Ajieh (2015) that inadequate fund, high cost of inputs, limited access to credit among others hinders farmers from getting the necessary resources and technologies which assist them to produce efficiently and remain in production. The implication is that farmers depend wholly on their small personal savings to finance their production activities which usually makes them unable to adopt technologies disseminated in the area as well as attaining large scale production.

Table2. Mean Score of Constraints to Adoption of Sweet Potato Production Technologies

\begin{tabular}{|l|l|l|}
\hline Constraints & Mean $(\bar{x})$ & $\begin{array}{l}\text { Standard } \\
\text { Deviation }\end{array}$ \\
\hline Inadequate capital for start-off & $3.00^{*}$ & 0.000 \\
\hline Limited access to credit facilities & $2.94^{*}$ & 0.239 \\
\hline High incidence of pest and disease infestation & $2.94^{*}$ & 0.239 \\
\hline High cost of inorganic fertilizers & $2.93^{*}$ & 0.256 \\
\hline Inadequate agro-inputs incentives like herbicides, fertilizer & $2.86^{*}$ & 0.349 \\
\hline High cost of labour & $2.84^{*}$ & 0.443 \\
\hline Unavailability of improved planting materials & $2.82^{*}$ & 0.479 \\
\hline High cost of improved varieties & $2.75^{*}$ & 0.520 \\
\hline Poor road network for produce transportation & $2.73^{*}$ & 0.510 \\
\hline Herdsmen attack/cattle menace & $2.65^{*}$ & 0.672 \\
\hline Poor soil fertility & $2.59^{*}$ & 0.818 \\
\hline Inadequate technical knowledge of improved agronomic practices & $2.58^{*}$ & 0.727 \\
\hline Poor yield & $2.29^{*}$ & 0.756 \\
\hline Rodents attack & $2.07^{*}$ & 0.685 \\
\hline Poor storage facilities & $1.95^{*}$ & 0.672 \\
\hline Inadequate cultivate land & $1.90^{*}$ & 1.267 \\
\hline Poor market & $1.81^{*}$ & 0.800 \\
\hline Use of local varieties & $1.79^{*}$ & 0.832 \\
\hline Poor extension contact & $1.66^{*}$ & 0.742 \\
\hline Bush burning/ fire outbreak & 1.47 & 0.846 \\
\hline Too much rainfall & 0.99 & 0.798 \\
\hline $\begin{array}{l}\text { Difficulty in integrating sweet potato production technology into } \\
\text { existing production system }\end{array}$ & 0.91 & 1.016 \\
\hline
\end{tabular}

$\bar{x} \geq 1.5=$ major constraint*

\section{Factor analysis of constraints to adoption of sweet potato production technologies}

Table 3 shows the results of the rotated factor analysis indicating the extracted factors based on responses of the respondents on constraints to adoption of sweet potato production technologies. The constraints to adoption of sweet potato production; factors 1,2 and 3 were named input, climatic and poor management factors, respectively.

Input constraints included lack of market (0.703), high cost of improved varieties $(0.583)$, poor road network for produce transportation (0.627), poor yield (0.750), lack of technical knowledge of improved agronomic practices $(0.818)$, poor soil fertility $(0.765)$, poor storage facilities $(0.683)$ and inadequate agro- inputs incentives like herbicides. The finding implies that the producers are highly constrained by these factors in the study area as they were unable to access these inputs at subsidized rate from government approved agencies or agro dealers and as such has no option than to buy from open market at exorbitant cost. This agreed with the report of the National Agricultural Extension Research Liaison Services (NAERLS) and Federal Ministry of Agriculture and Rural Development (FMARD) (2014) identified exorbitant cost of fertilizer, agrochemicals and other inputs as serious constraints to enhanced agricultural production in the area.

Climatic constraints included too much rainfall (0.811), bush burning/ fire outbreak (0.782), high cost of inorganic fertilizer (0.627), difficulty in integrating sweet potato production technology into existing production system (0.715), use of local varieties (0.497) and high cost of labour (0.486). This implies that producers identified inadequate fund as a barrier in adopting sweet potato production 
Socio-Economic Factors Influencing Adoption of Sweet Potato Production Technologies among Farmers in South East, Nigeria

technologies in the area. The findings are in line with Okoro and Ajieh (2015) who stated that inadequate fund hinders farmers from getting the necessary resources and technologies which assist them to produce effectively and remain in production.

Poor management constraints as indicated in Table 3 included high incidence of pests and diseases infestation (0.694), rodent attack (0.585), limited access to credit facilities (0.601) and poor extension contact $(0.714)$. This implies that the producers in the study area are poorly visited by extension agents to ascertain their farming problems, know where they need assistance and disseminate improved technologies to them. This could negatively hinder their adoptive capacity in the adoption of sweet potato production technologies. Similarly, this may also impede their effective production and profit realized from the adoption of improved technologies. This is in line with Ayoola (2012) who noted that there is poor knowledge of improved production techniques which was caused by inactive extension system. However, the dearth of quality extension service in the study area is responsible for low output of extension agents leading to poor adoption of improved technologies resulting in poor yield.

Table3. Factor Analysis of Constraints to Adoption of Sweet Potato Production Technologies

\begin{tabular}{|c|c|c|c|}
\hline Constraints & $\begin{array}{l}\text { Factor } 1 \\
\text { (Input } \\
\text { constraints) }\end{array}$ & $\begin{array}{l}\text { Factor } 2 \\
\text { (Climatic } \\
\text { constraints) }\end{array}$ & \begin{tabular}{|l} 
Factor 3 \\
$\quad$ (Poor \\
management \\
constraints)
\end{tabular} \\
\hline High incidence of pests and diseases infestation & 0.019 & -0.037 & -0.694 \\
\hline Poor market & -0.703 & -0.075 & 0.208 \\
\hline Too much rainfall & 0.090 & 0.811 & -0.125 \\
\hline Unavailability of improved planting materials (vine) & 0.733 & -0.494 & 0.260 \\
\hline High cost of improved varieties & 0.583 & 0.332 & -0.331 \\
\hline Rodents attacks & 0.011 & -0.144 & 0.585 \\
\hline Bush burning/fire outbreak & 0.128 & 0.782 & 0.168 \\
\hline Inadequate cultivable land & 0.631 & 0.562 & -0.404 \\
\hline Herdsmen attack/cattle menace & 0.765 & -0.451 & -0.073 \\
\hline High cost of inorganic fertilizer & 0.267 & -0.627 & 0.195 \\
\hline $\begin{array}{l}\text { Difficulty in integrating sweet potato production } \\
\text { technology into existing production system }\end{array}$ & 0.142 & 0.715 & -0.393 \\
\hline Use of local varieties & -0.164 & 0.497 & 0.371 \\
\hline Poor road network for produce transportation & 0.627 & -0.139 & -0.028 \\
\hline Poor yield & -0.750 & -0.140 & 0.263 \\
\hline Limited access to credit facilities & -0.039 & 0.087 & -0.601 \\
\hline \begin{tabular}{|lll} 
Inadequate technical knowledge of improved \\
agronomic practices
\end{tabular} & 0.818 & 0.304 & 0.128 \\
\hline Poor soil fertility & 0.765 & 0.340 & 0.184 \\
\hline Poor extension contact & -0.254 & 0.205 & 0.714 \\
\hline Poor storage facilities & $-\mathbf{0 . 6 8 3}$ & -0.070 & 0.273 \\
\hline High cost of labour & 0.247 & 0.486 & 0.117 \\
\hline $\begin{array}{l}\text { Inadequate agro-inputs incentives like herbicides, } \\
\text { fertilizer. }\end{array}$ & 0.740 & -0.053 & 0.383 \\
\hline
\end{tabular}

\section{CONCLUSION AND RECOMMENDATIONS}

Results of the study indicated that socio-economic factors such as age, educational level, farming experience, membership of organization, access to extension services and annual income had significant relationship on adoption of sweet potato production technologies in the study area. Major constraints to adoption of sweet potato production technologies include inadequate capital for startoff, limited access to credit facilities, high incidence of pests and diseases infestation, high cost of 
inorganic fertilizer, inadequate agro-input incentives like herbicides, high cost of labour, unavailability of improved planting material (vine), high cost of improved varieties, poor road network for produce transportation, herdsmen attack/cattle menace, poor soil fertility, etc.

It is recommended that there is a need to improve the productivity of farmers by encouraging increased use of improved technologies through practical oriented short training program designed to build the capacity of the producers and adequate provision of facilities that will be appropriate for its usage in order to maximize profit. The study also highlights that efforts of the federal government is required in providing farm inputs such as fertilizer and herbicides at a subsidized rate in order for it to be affordable by the farmers to boost production.

\section{REFERENCES}

[1] Abubakar, H.N., Olayiwola, I.O., Sanni. S. A. and Idowu, M. A. (2010). Chemical composition of sweet potato (Ipomea batatas Lam) dishes as consumed in Kwara State, Nigeria. Journal of International Food Research, 17(2), 411-416.

[2] Ajah, J. (2015). Comparative analysis of cooperative and non-cooperative farmers access to farm inputs in Abuja, Nigeria. European Journal of Sustainable Development. 4(1), 39-50.

[3] Anambra State Agricultural Development Programme (ASADEP) (2013). Tips on Commercial Production of Cassava, Awka, Nigeria: Monitor, Implementation and Completion Report, Kucerna Damian Press, pp. $4-5$.

[4] Alinor, A.N. (2002). Economic study of cassava processing in Nsukka agricultural zone of Enugu State. Unpublished M.Sc Thesis. Department of Agricultural Economics, University of Nigeria, Nsukka.

[5] Aniedu, C. and Aniedu, O.C. (2013). Gender mainstreaming in agricultural development in Nigeria. In agricultural extension and rural development. Nwachukwu. I (ed). Lamb House Publication Umuahia. Journal of Community and Communication Research, 2(1), 68-69.

[6] Ayoola, J.B. (2012). Socio-economic determinants of the adoption of yam minisett technology in the middle belt region of Nigeria. Journal of Agricultural Science, 4(6), 217-218.

[7] Ejechi, M.E., Aboaja, F.N; Anyaebunam, H.N; Asumugha, G.N; Njoku, J.C and Okoye B.C. (2010). Role of women in sweet potato production in federal capital Territory. National Root Crop Research Institute (NRCRI) Umudike, Abia State. Annual Report.

[8] Federal Government of Nigeria (FGN) (2011): Transformation Agenda 2011-2015. Summary of Federal Government key Priority Policies, Programmes and Projects.

[9] Federal Ministry of Agriculture and Rural Development (FMARD) (2014). 10 Million Farmers Captured in Agric E-wallet Scheme. New Telegraph. Retrieved on 15 ${ }^{\text {th }}$ March, 2015 from newtelegraphonline.com, Abuja, Nigeria.

[10] Food and Agricultural Organization (FAO) (2012). Report on joint FAO Expert Committee in energy and protein requirement. Rome, FAO.

[11] International Potato Centre (CIP) (2010). Orange-fleshed Sweet potato for Africa Catalogue 2010. Lima, Peru International Potato Centre. Retrieved from http://cipotatoorg/publications/pdf/005374.

[12] Ministry of Agriculture Awka (2015). Annual Report, 2015, Awka, Anambra State, Nigeria. Kucena Damian Press.

[13] National Population Commission (NPC) and ICF Macro (2009). Nigerian Demographic and Health Survey (NDHS) 2008: Key findings. Calverton, Maryland, USA: NPC and ICF Macro, Analytical Report of National Level. Onwa press. pp. 20-25.

[14] National Root Crops Research Institute (1990). Annual Report of the National Root Crops

[15] Research Institute, Umudike

[16] .

[17] National Root Crops Research Institute (NRCRI) (1996). Evaluation of selected genotypes of sweet potato in different ecological zones of Nigeria. Annual Report of the National Root Crops Research Institute, Umudike.

[18] National Root Crops Research Institute (NRCRI) (2009). National Root Crops Research Institute, Umudike- Root Crops Division. http://74.6.239.67/search/cache?ei=UTF8\&p=www.nrcri.org\%2fpages\%2fspotato.htm\&i.

[19] Nigerian Demographic Health Survey (NDHS) (2008). National Population Commission, Abuja, Nigeria.

[20] Nwachukwu, I. (2014). From drum beats to gigabytes: Communicating agricultural innovations effectively to farmers. Inaugural lecture, Michael Okpara University of Agriculture, Umudike. 
[21] Nwaigwe, G.O., Echendu, T.N., Nwankwo, I.I.M., Ewuziem, J.E., and Nwako, E.N. (2011). Accessibility of improved Sweet Potato Planting Materials to Farmers in Abia State. Proceedings of the $45^{\text {th }}$ Conference of Agricultural Society of Nigeria (ASN) 24 ${ }^{\text {th }}-28^{\text {th }}$ October "UDS2011" (supplement) pp.71-76.

[22] Nwinyi, S.C.O. and Onyenobi, V.O. (1987). Effect of sweet potato vine preservation method on yield. Annual Report of the National Root Crops Research Institute, Umudike.

[23] Ochuba, N. O., Ogbuehi, B. R. A., Okonkor, A. C., Nnodu, E. C. and Emelute, J.K.U. (1983). Evaluation of sweet potato cultivars for high yield and resistance to pests and diseases. Annual Report of the National Root Crops Research Institute, Umudike, Abia State, Nigeria.

[24] Ogbonna, M.C., Nwauzor, E.C., Asumugha, G.N., Emehute, J.K.U., Korieocha, D.S. and Anyaegbunam, H.N. (2005). Cost and return analysis for the production of sweet potato in Nigeria: A case study of NRCRI, Umudike. Annual Report of the National Root Crops Research Institute, Umudike, Abia State, Nigeria.

[25] Okoro, B.O. and Ajieh P.C (2015). Farmers Perception and Adoption of Yam Minisett Technology in Anambra State, Nigeria; Global Journal of Science Frontier Research: Agriculture and Veterinary, 15(8), $36-40$.

[26] Okoye, A.C., Dimelu, M.U., Okoye, B.C. and Agwu, A.E. (2009). Gender constraints in small holder cocoyam production in Enugu North agricultural zone of Enugu State, Nigeria. Global Food Crisis and Nigerian proceedings of the $43^{\text {rd }}$ Annual Conference of Agricultural Society of Nigeria. pp. 30-35.

[27] Olufloaji, A. (2012). The Role of Research Agricultural Development Occasional Series of National Horticultural Research Institute (NHORT) Ibadan, Oyo State, Nigeria.

[28] Reaching Agents of Change (RAC) (2012). Sweet Potato facts and fiction Centre for International Potato (CIP), Nairobi. www.sweetpotatoknowledge.org

[29] Ugwumba, C.O.A. and Omojola J.T (2012). Socio-Economic Determinants and Profitability of Yam Production in Ipao-Ekiti, Nigeria. Journal of Science and Multidisplianary Research, 4(1), 46-55.

[30] United Nation Administrative Committee on Coordination. Subcommittee on Nutrition (1994). Controlling vitamin A deficiency Nutrition policy Discussion paper, vol. 14(1), pp. 82-86.

[31] Woolfe, J. (1992). Sweet potato: An Untapped Food Resources. Published in collaboration with the International Potato Centre, Peru. Cambridge University Press, Cambridge. UK. Nigerian Agricultural Journal 47 (1), 335-346.

Citation: Okeke, M.N. and Mbah, E.N. (2021). "Socio-Economic Factors Influencing Adoption of Sweet Potato Production Technologies among Farmers in South East, Nigeria.", International Journal of Research Studies in Agricultural Sciences (IJRSAS), 7(6), pp. 7-15 DOI: http://dx.doi.org/10.20431/24540706002.

Copyright: () 2021 Authors. This is an open-access article distributed under the terms of the Creative Commons Attribution License, which permits unrestricted use, distribution, and reproduction in any medium, provided the original author and source are credited. 